\title{
The work of university research administrators: Praxis and professionalization
}

\author{
Sandra Acker, Michelle K. McGinn, and Caitlin Campisi ${ }^{1}$
}

\begin{abstract}
As part of a project on the social production of social science research, 19 research administrators (RAs) in five Canadian universities were interviewed about work, careers, and professionalization. While rarely featured in the higher education literature, RAs have become an important source of assistance to academics, who are increasingly expected to obtain and manage external research funding. RAs perform multiple roles, notably assisting with the complexities of grant-hunting as well as managing ethical clearance, knowledge mobilization, and related activities. Aspects normally associated with professionalization include organizations that control entry, higher degrees in the field, and clear career paths, all of which are somewhat compromised in the case of RAs. Nevertheless, most of the participants regard research administration as a profession, and we argue that it is more important to focus on the sensemaking and identity formation of these mostly female staff than to apply abstract criteria. Although their efforts do little to challenge a culture of performativity in the academy, and indeed may be regarded as supporting $i$, the RAs have defined for themselves a praxis dedicated to easing the burdens of the academics, helping one another, and contributing to the greater good of the university and the research enterprise.
\end{abstract}

Received 30 August 2019; revised version received 8 October 2019; accepted 18 October 2019. Corresponding author: Sandra Acker, University of Toronto, Canada (sandra.acker@utoronto.ca).

As government funding for universities declines, and universities increasingly mimic corporations, individual academics are encouraged, or even compelled, to obtain research funding from external sources. At the same time, grant-hunting has become ever-more complicated (Luukkonen \& Thomas, 2016). It follows that at least some academics may need assistance to navigate these complexities.

\footnotetext{
${ }^{1}$ This work has been funded in part by the Social Sciences and Humanities Research Council of Canada (435-2017-0104). We are grateful to the research administrators who participated in the study, and we also acknowledge the help and support of additional members of our research team, Marie Vander Kloet, Anne Wagner, and Pushpa Hamal, and others who have contributed in various ways, Margaret Brennan, Lara Cartmale, Victoria Kannen, and the JPHE Editor in Chief and reviewers.
} 
Consequently, we see the expansion of a cadre of research administrators dedicated to assisting faculty in this pursuit and, in some cases, performing other research support roles. ${ }^{2}$ It is tempting to link research administration's increasing pro-minence with the surge of managerialism and regulation that has accompanied the neoliberal transformation of universities (McGinn, 2012; Shore \& Wright, 2015) and with encroachments upon academics' traditional independence and autonomy (Ginsberg, 2011). However, our purpose is not to impose an external judgement or critical commentary upon the part research administrators may play in supporting a neoliberal agenda, but to focus on the interpretations research administrators themselves give to their roles, their careers, and their field's professional status.

Research administrators have received relatively little attention from higher education scholars, reflecting the general tendency of the literature to focus on academics rather than other university staff. Many of the studies that do exist combine administrative staff with very different roles, thus making it difficult to say much about a specific group such as research administrators. Other studies make generalizations about 'administrators', blurring the distinction between senior academics in managerial roles and professional staff.

This article reverses the typical focus of higher education scholarship by moving academics out of the limelight and foregrounding instead research administrators, whose contribution to the successes attributed to academic others may be substantial. Moreover, the article adds a Canadian perspective, generally missing from the international literature on university administrative staff. It also addresses questions around whether research administration can be considered a profession, what elements of praxis are involved in the practice of research administration, and how to respond when research administrators' perceptions seem at odds with prevailing ideas in some of the literature on professions or on neoliberal tendencies in universities.

As part of a project on the social production of social science research in Canada, we interviewed 19 research administrators in five universities. Given that so little specific research exists on the work of this occupational group, our overall research question is simply, 'How do research administrators in Canadian universities understand their work?' We probe more deeply with our subquestions, which are:

1. Do research administrators see their field as a profession and if so, are there elements of praxis involved?

\footnotetext{
${ }^{2}$ In this article, we use the Canadian terminology of administrator, rather than manager or developer, and faculty, rather than or in addition to academic staff. The term 'faculty' may also describe a disciplinary-based unit, such as a faculty of arts.
} 
2. What aspects of research administrators' work contribute to or contradict this image of research administration as a profession?

In the discussion section, we build from these results to consider what tensions may obtain between the sensemaking of these research administrators about their work and the prevailing critiques of universities as increasingly corporatized, managerial, and audit-based. Before turning to our findings, we review the major concepts that inform our analysis, present relevant literature on professions and research administration, and describe the details of our study.

\section{Conceptual framework}

Our primary concepts are sensemaking, praxis, and profession. Degn (2018) extends the sensemaking perspective, derived from Weick (1988) and popular in organizational theory, to 'academic sensemaking', that is, 'the way academics make sense of their changing circumstances, and how this affects their perceptions of their organization, their leaders and of themselves' (p. 306). Earlier usages of the sensemaking framework pertained to responses to specific events such as crises, but the purview has widened to consider situations of rapid organizational change (Maitlis \& Sonenshein, 2010, p. 558), which would seem to describe contemporary academe. The notion of sensemaking can be extended from academics to research administrators.

We also invoke the concept of praxis. Praxis involves inserting a theory or idea into one's practice, making it purposeful and, in most cases, oriented towards change that 'contribute[s] to the good for each person and the good for humankind' (Kemmis, 2012, p. 903). When discussed in the higher education literature, praxis is most often associated with academics' classroom pedagogy, action research, or service to the community (e.g., Kozaitis, 2013), although there is no reason not to include other university staff. Kemmis (2012) distinguishes between 'spectator' research, which may be appropriate when identifying factors that shape the responses and choices of those studied, and research conducted from the participant perspective, where people examine and improve their own lived realities through praxis. We are not research administrators, so there is inevitably an element of spectatorship in our research; however, as 'co-habitants' (Kemmis, 2012) in the university research enterprise, we are implicated in the practices we study. It is our intention to respect the interpretations of the participants.

We believe that understanding the ways in which people in this occupation see themselves as engaged in a praxis and a profession is an important 
contribution to the higher education literature. Investigating the perceptions (sensemaking) of our participants about research administration as a profession gives us insights into their individual constructions of professional identity and into the field's professionalization efforts. Our third main concept—professionis discussed in more detail in the following section, which also introduces literature about research administration.

\section{Research administration and the sociology of professions}

The sociology of professions is a vast and contested field. Much effort has been expended on determining which occupations qualify for the designation. Over time, the prevailing interest has changed (for overviews, see Adams, 2015; Evetts, 2011; Martimianakis et al., 2009). Generally speaking, scholars have moved away from identifying a set of traits critical to determination of a profession to a series of additional questions, such as 'What mechanisms do occupations use to restrict entry?'; 'What roles do professions play in social stratification and power struggles?'; and 'How do occupations lay claim to professional status?' Recent interest has shifted to the negotiations and compromises required of professionals in corporatized public sector settings, where professional claims to expertise clash or combine with managerial forms of control (Noordegraaf, 2007; Paton et al., 2013; Reed, 2018).

Research administration has been defined as 'the leadership, management or support of research activities' (Kerridge \& Scott, 2018, p. 2). It is one of many diverse occupations seeking professional recognition and thus status and respect. It is generally considered to be located within academic institutions, although other sites, such as hospitals, non-profit organizations, and government agencies, are possible.

University research administrators, our focus in this study, work at various points of what is typically called the research life-cycle. A conventional distinction in this cycle, one that we heard often in our interviews, is between 'pre-award' and 'post-award' responsibilities. The former involves 'the identification of funding opportunities, proposal development, costing, internal approval, and submission to the prospective funder' while the latter is concerned with 'financial management and reporting, partner agreements, and reports to the funder' (Zornes, 2019, February, slide 6). Some responsibilities cross this divide, such as strategic projects or research ethics management, as well as leadership roles supervising others and contributing to institutional policy. In a large institution, the work may be subdivided into relatively small parts and there may be both centralized and decentralized administrators, the latter working in a 
faculty, research centre, or department, while in a small university, centrally located research administrators may cover activities across the board.

Various authors note that university administrators are frequently women (Allen-Collinson, 2007, 2009; Eveline, 2004; Krug, 2015; Losinger, 2015; Pearson, 2008; Ricketts \& Pringle, 2014; Simpson \& Fitzgerald, 2014; Szekeres, 2004). Eveline (2004) contends that much of the 'glue work' involving repairs to interpersonal relations is done by women in administration, a point echoed by Losinger (2015) and Allen-Collinson (2006). The fact that this form of labour is largely female is likely related to its 'unacknowledged value' (Angervall et al., 2015).

Research administration follows this general trend of feminization. Shambrook et al. (2015, October) indicate that, in the United States, research administration has changed over time from a male-dominated to a femaledominated field. Internationally, about $77 \%$ of research administrators identify as female (Kerridge \& Scott, 2018, p. 26) and in Canada, the figure is even higher at $81 \%$ (Zornes, February, 2019). There is also international evidence that, as in many fields, men are over-represented in leadership roles (Kerridge \& Scott, 2018, pp. 26-27).

Variations in terminology across (and within) countries can make it difficult to apply findings from one jurisdiction to another. In Australia, dissatisfaction with the labels of 'general staff' and 'non-academic staff' has led to a substitution of 'professional staff' as the preferred designation (Sebalj et al., 2012). Different national usages of 'management' and 'administration' have also caused confusion (Szekeres, 2004). What in Canada is likely to be termed a 'research administrator' may be called 'strategic research support' in Sweden (Ryttberg \& Geschwind, 2017), a 'research development officer' in Australia (Berman \& Pitman, 2010, p. 165), or an 'income capture officer' in the UK (Cox \& Verbaan, 2016, p. 321).

Role variations go beyond nomenclature. The size, historical status, and level of research intensiveness varies across institutions. Moreover, there are also major differences from one country to another in how research is funded (Acker \& Ylijoki, 2018, July). If, for example, external research assessment exercises are linked to funding, administrative staff will have to assume responsibilities for data collection and reporting not fully duplicated elsewhere.

It is logical to expect that research administration work has changed in parallel with changes in knowledge production, university orientations, and technological innovations. The world of research now includes conformity to published ethical standards, open access commitments, web-based grant applications and ethics review processes, bibliographic and project management software, and other technical and accountability innovations and requirements. A principal investigator with a funded project will not only work with co- 
investigators and research assistants, but also interact regularly with university personnel such as librarians, information technology staff, departmental business officers, and research administrators (Cox \& Verbaan, 2016). Research administrators themselves must keep up with rapidly changing flows of information (Karlsson \& Ryttberg, 2016).

There are debates in the literature as to whether the administrative component of universities has grown at the expense of the (permanent) academic labour force (Gornitzka \& Larsen, 2004; Karlsson \& Ryttberg, 2016). Macfarlane (2011) argues that 'all-round' academics are being displaced by 'para-academics', including specialists such as 'student skills advisers, educational developers, learning technologists and research management staff' (p. 59). Whitchurch (2008) refers to 'blended professionals' who work in the 'third space', an emergent territory between academics and administrators. Shelley (2010) describes a range of academic-type duties carried out by research managers in the UK.

In general, these authors contend that, despite new administrative roles often being located in the 'back office' (Ryttberg \& Geschwind, 2017, p. 343), the functions they provide and consequently the people who provide them are crucial to the operations of contemporary universities. For example, Berman and Pitman (2010) state that 'a layer of professional roles central to the operations of universities has arisen in areas such as student services, international operations, alumni services, marketing and public relations, human resource management, information sciences, research commercialization and research management' ( $\mathrm{p}$. 157). Karlsson and Ryttberg (2016) call these service providers 'administrative professionals'. Larson (2018) offers 'techno-bureaucratic professions'. But is university administration a single profession or many? In particular, how do research administrators understand the parameters of their work?

\section{Methods}

As part of a larger study on the construction of social science research, 19 qualitative, in-depth interviews were conducted in 2018-19 with staff members holding research administration responsibilities in universities in Ontario, Canada. Although their titles varied, as did the extent to which they had line management roles, nearly all described themselves as research administrators (hereafter, RAs). ${ }^{3}$

\footnotetext{
${ }^{3}$ We are not including staff who are employed as managers of individual projects or whose main responsibility is related to higher degree student research, although some of our participants occasionally contribute to those areas. Nor are we including academic administrators (managers) such as associate deans or vice-presidents with responsibilities for research.
} 
The RAs were affiliated with five Ontario universities at various levels of research-intensiveness. They were identified through website searches, personal contacts, and referrals from other participants. Although we gave preference to individuals with responsibilities related to the social sciences (including education and social work), we included a broader range of participants to cover a variety of specialties within the research administration category (e.g., research information analysis, research ethics management, and knowledge mobilization). Participants worked in pre-award and/or post-award sectors, in specialized areas, and in central administrative offices or decentralized units such as faculties or research centres. Our selection of participants followed national trends in that the majority, about three-quarters, were women (Zornes, 2019, February); most of the men and about a third of the women were in the most senior position of director. These promotions were related to age and experience, however, so we cannot readily say that gender alone is implicated in giving men an advantage. Nevertheless, the distribution is suggestive and parallels other literature on gendered work among academics (Acker \& Dillabough, 2007; Angervall \& Beach, 2017) and administrators (Kerridge \& Scott, 2018; Simpson \& Fitzgerald, 2014).

The questions that were addressed covered academic background and current responsibilities, as well as opinions on a range of issues and policies. The semi-structured nature of the interview guide meant that participants could elaborate on those areas that were most meaningful to them.

The members of the research team secured clearance for the study from their universities' research ethics boards and those of other institutions that required it, and all interviewees provided voluntary consent prior to participation. Three academics on the team conducted the interviews. Although we did not discern any untoward consequences of the fact that we were academics interviewing administrators, it is possible that participants tempered any potentially unflattering statements about academics in order to ensure the interview proceeded comfortably. Interviews lasted from 75 to 90 minutes and were transcribed in full. The names used below are pseudonyms.

We conducted iterative-inductive thematic analysis, building from open and provisional codes toward key themes and analytic insights (Cascio et al., 2019; Charmaz, 2010). The engagement of multiple team members strengthened the confidence in the analysis (Cascio et al., 2019). This article focuses specifically on the professionalization theme that arose across interviews.

The results of our study are discussed in the two sections that follow. In order to answer the first research sub-question, we consider the responses of the RAs to questions about research administration as a profession. When discussing such issues, the participants reveal the extent to which they see their practice as 
praxis. Next, in line with the second research sub-question, we isolate some of the aspects of professions commonly cited and note how our participants' experiences compare.

\section{RAs' views of the profession}

This section concerns the sensemaking of participant RAs with regard to their understanding of the professional status of their occupation and the extent to which praxis is involved in their work. In the process of responding, participants generally defended the professionalization of research administration, indicated various forms of praxis (although not by name), stressed the ways their field had changed and was changing, and emphasized the centrality of helping academics do their work. When asked directly whether they saw research administration as a profession, responses included 'yeah, it's clear' (Amanda Gilbert); 'absolutely, it is' (Andrea Young); 'absolutely, absolutely' (Robert Walker); and 'yes, for sure, definitely' (Megan Lewis). Dissenting views included Kelly Andrews's comment 'I've only seen it as a livelihood' and Deborah Cooper's objection to the implied elitism that she saw in the term 'profession'.

\section{A changing profession}

In answering our questions about research administration as a profession, participants often explained how their views or the field had changed over time. Andrea Young noted, 'I can see that now in a way that I couldn't a couple of years ago', a development she related to the increasing pressure on academics to acquire external grants and the growing complexity of the process. Bruce Fitzgerald had also changed his assessment:

I may not have [seen research administration as a profession] at first /.../ but I do now, because research and innovation is on everybody's mind right now as a future area of economic growth, let alone the merit of it from a research and academic exploration perspective.

Discussions of professionalization tended to overlap with commentary on change. Andrea and Bruce's remarks are examples of sensemaking in situations of rapid institutional change. Participants were aware that 'the research landscape is rapidly changing and evolving' (Candace Vernon) and that RA work had moved from 'checking boxes, what attachments, what components need to be included /.../ to much more imaginative work' (Amanda Gilbert). Pauline Emerson concluded that because there is less of the 'boring, laborious work' to do, 
'technology has changed [things] for the better'. Others were less sure. Constantly upgraded technology in one institution had led to difficulties for academics and administrators alike (cf. Szekeres, 2011, p. 683), as Candace Vernon indicated:

What has changed? Definitely I feel like [it's] this digital piece, trying to adopt these digital systems to help bring about efficiencies in research administration, and to me the jury's really out on whether that is the case and whether it creates any efficiency or displaces inefficiency.

One change mentioned by several participants was the rise in the importance of demonstrating research impact or what was locally called 'knowledge mobilization'. Stephen Osborne noted that his unit 'focusses on, not just the inputs to research but the outputs of research, so the publications, the performances, the patent applications'. He continued:

So community engagement, public engagement would form the type of work that we do. And then research happens in the knowledge mobilization space often co-created with partners /.../ and that's all part of the innovation space, and then also there's the dissemination. How do we get it out? How do we mobilize that? How do we help researchers facilitate the uptake of evidence by policymakers, community partners, industry, government?

Robert Walker pulled together several aspects of research administration's professionalization project and its intertwining with change:

[People in this field] /.../ we came to it through happenstance, an opportunity that emerged that aligned with our skill sets, but [with the] increasing needs federally for accountability and transparency around such things, and with increasing competition across the country or internationally for such things, we've kind of upped the ante collectively on what constitutes a strong proposal, what constitutes good governance, what constitutes robust administration and management and compliance with research. So it's a growing space. It's forced itself to sort of become professionalized.

Robert's statement indicates a contribution to strengthening the research profile of the university as a whole. Also embedded is the determination that research administrators have 'upped the ante' or increased the quality of the work being done by researchers and universities. Claims like Robert's can be regarded as signalling a form of praxis. 


\section{A helping profession}

Note that in the quotation above, Stephen said, 'we help researchers'. 'Helping' was a dominant motif across the interviews. It was especially apparent for RAs with pre-award or across-the-board responsibilities who tended to emphasize contributions to faculty success and well-being. For example, they contacted new faculty early in their appointments in order to help them plan their research careers: 'We'll meet with the new faculty and kind of develop a plan for them, and tell them what the expectations are /.../ and what grants to go for and what not to go for. So you get rid of a lot of anxiety' (Pauline Emerson).

The RAs also worked with more senior faculty when requested, as changing technological and substantive requirements of the funding bodies challenged everyone (McGinn et al., 2019). Pauline's reference to reducing anxiety suggests that a form of help may be emotional rather than or in addition to technical. Some RAs referred to their work as counselling or coaching, especially when grant applications were unsuccessful and faculty were upset: 'Sometimes you have to talk people off the ledge. People can be very angry in June when they get their comments [from the research council]' (Eric Lowe). Karen Douglas, who described these rejections as producing 'crushing emotion', added that her job also had the practical side of finding other sources of funding for such individuals. She stressed that she enabled rather than instructed:

I would never want to be in a position of directing where we think, institutionally, researchers should put their efforts /.../ The interest of the faculty members would be realized in terms of how we shape what happens institutionally /.../ So I always feel like what I'm around for is leading my team, thinking about one-on-one supports for researchers, if they want to plan their careers. I have lots of specific grant knowledge that we try and share. I see my role as attempting to connect people to other researchers or sort of as an information-gathering role that can help enable research to happen.

The RA identity builds on helping others and in doing so, RAs feel personal satisfaction, as these two quotations illustrate:

[In the pre-award sector] we can focus really on helping the researchers on building an environment and a culture that will be supportive for faculty. I love that part. I think I've got one of the best jobs in research administration /... I'm dealing with helping the researchers achieve their goals. (Eric Lowe)

I think things are becoming more complicated and I think that those who stay in the field and want to improve how we do things really are dedicated 
to the idea that the better we are at the work we do, the more time the faculty member ultimately has to spend on their research and that matters to a lot of us, although I recognize that we're also seen as a bureaucracy by many. (Bruce Fitzgerald)

Despite the potential for negative reactions from those they seek to assist ('seen as a bureaucracy'), there is evidence here that these RAs engage in praxis. In striving to make things better for their academic counterparts, the RAs' sensemaking keeps them motivated by believing that they are making a difference to the careers of others and the future of the university.

\section{Aspects of a profession}

Across the varied and contested assertions about what constitutes a 'profession', some key aspects include associations, a specialized body of knowledge, higher qualifications, and clear pathways into and through a career in the field (Szekeres, 2011). Participants' comments on each of these areas raise many points of difference between what might be expected of a profession and the characteristics and career pathways found in research administration. Serendipity in becoming a research administrator, learning 'on the job', and uncertain career prospects were all mentioned. Praxis is suggested too, as the gaps in formal training are addressed by informal efforts at creating self-help groups or 'communities of praxis' (Anderson \& Freebody, 2012).

\section{Associations}

Our findings parallel Shelley's (2010, p. 53) observation that research administrators do not generally affiliate with higher education societies but prefer specialty RA associations. Many participants mentioned the conferences of the Canadian Association of Research Administrators (CARA) as the 'go-to place for developing a career in research administration' (Robert Walker). CARA has over 1000 members and describes itself on its website as 'a national voice for research administrators in Canada'.

While CARA and other similar associations are engaged in professional development, hold conferences, and publish newsletters and in some cases journals, they do not control entry to the field, one of the characteristics often associated with professionalization. In fact, as we show below, entry to the field of research administration occurs along many pathways and is frequently serendipitous.

\footnotetext{
${ }^{4}$ https://cara-acaar.ca/about (2019-10-18).
} 


\section{Specialized knowledge}

A specialized body of knowledge was evident when participants described their work responsibilities, although it varied from one role to another, and its acquisition often seemed haphazard. A certificate program had recently been developed by CARA, starting in 2017 , in conjunction with a community college (Mohawk College), but was not mandatory, and our RA participants had not attended it. We were told that there were several degree programs in the United States, but not in Canada: 'Canada is a baby in terms of research administration, [whereas] the US is like a PhD student' (Eric Lowe).

In all of the universities represented in the study, there was an absence of sustained professional development activity that would help new RAs learn their craft: 'absolutely none at all, absolutely none at all' (Erin Bell). Learning might take place through other means, for example, 'I learned a lot from going to conferences, participating in conversations with more seasoned researchers or faculty members or employees' (Angela Gordon); 'I went to the CARA conference this year in May and it was a great experience for me and I learned about many resources' (Cynthia Quinn). Most of the participants spoke of learning 'on the job': 'It was almost $100 \%$ on the job' (Eric Lowe); 'a learn-asyou-go thing' (Jason Thorne). Candace Vernon commented that 'until quite recently, there was no structured training at all. It's sort of baptism by fire'.

Responding to the lack of university-based professional development, participants described informal and proactive efforts at workplace learning made by RAs in their institutions, which we could reframe as examples of praxis, in the sense that they are efforts to improve their own and their colleagues' work lives. For such initiatives to flourish, they need time, space, and trust (Mahon et al., 2019), which may be more readily available in some sites than others. According to Anderson and Freebody (2012), while communities of practice are forums for collective learning, there are also communities of praxis, with a greater emphasis on reflection and applying theory to practical situations. One such group, mentioned by Kathryn Richards, was made up of institutional researchers within a large university; another was a network of research administrators that Karen Douglas described:

[At first] it was a place to complain a bit, but mostly to share best practice. And as the years have gone on /.../ we've given up on the complaining part and we look only to that part about what is best practice, how do we learn, who are we learning from, what did you do in this case.

Kelly Andrews belonged to a research administrator group in a different university that also shared information: 'it becomes this backdoor way of getting information that you actually need to do your job effectively'. 
Not everyone could benefit from communities of practice or praxis within their institutions. A few individuals like Rebecca Smith had very specialized job descriptions: 'I don't really think there's a community of practice that I fall into at this point'. Those RAs who worked in smaller universities had few colleagues to consult. Erin Bell was in that category:

\begin{abstract}
There were only two people in the office so I did /.../ everything from preaward administration of grants, development of grants, to the post-award administration of grants, which is letters of transfer funds, helping to set up research agreements, filing reports, doing knowledge mobilization activities including research week or conferences linked to the funded research, promoting the research through social media, doing large teaching grant applications. Basically anything I was asked to do that was related to research and then I also did research ethics.
\end{abstract}

Erin's description indicates the potential for becoming a 'Jill-of-all-trades' when providing research services in a small, predominantly undergraduate university. Being required to absorb 'specialist knowledge' in so many subfields may actually make the job more difficult than it is for RAs in larger, research-intensive universities where responsibilities are more segmented.

\title{
Qualifications
}

Interviews with the RAs began with questions about their academic backgrounds and careers. A frequent comment was a variation on 'none of us in this field ever said, as a child, I want to grow up to be a research administrator' (Robert Walker). Like participants in Karlsson and Ryttberg's (2016) Swedish study, our RAs were highly educated. Three held bachelor's degrees as their highest qualification, while the other 16 were equally split between those with master's degrees and those with doctorates. Interestingly, of the eight with doctorates, all but two had additional postdoctoral research experience, reporting up to three postdoctoral postings. As the three without higher degrees were all in the 50-plus age group, it appears that a master's degree has become the baseline expectation, consistent with Shambrook et al.'s (2015, October) findings from the United States.

The RAs' degrees were in many different fields. Given that there are no Canadian degrees in research administration, we can surmise that various skills learned in higher degrees, regardless of subject field, may provide a base for RA work. The prevalence of postdoctoral research was especially interesting as this finding has not been reported elsewhere. It may indicate that these individuals are comfortable with research and with universities as workplaces. When an opportunity for an administrative career appears, individuals with that profile may be likely to seize it. In addition to the six individuals who had conducted research 
as part of their postdoctoral appointments, another four spoke of prior employment as researchers. Most of these positions were in universities but a few were in other venues (e.g., non-profits).

We can speculate that one reason that qualifications for these positions have been rising may be the lack of opportunities in the full-time academic labour market (Acker \& Haque, 2017). The 'alt-ac' sector of relatively well-paid and secure administrative positions that most of our participants occupied provides an opportunity to stay in the university environment and be involved in some measure in research while avoiding the growing pressures placed upon academics (except vicariously) and bypassing or abandoning the difficult search for a permanent academic position (Campisi \& Vander Kloet, 2019, June).

It could also be said that these RAs enjoyed learning for its own sake and for ideas they could incorporate into their work. As well as online higher degrees such as MBAs, participants gave examples of additional courses and certificates they had embarked upon, including project management, mentoring, coaching, knowledge translation, and career development.

\section{Pathways in and through careers}

Given that research administration associations do not control entry into the field, and there are no specific degree qualifications available, how do people arrive there and what career paths are available to them? Pathways varied. Several participants had worked in a university or universities for a long time, transitioning from one research or administrative position to another, often posts with significant degrees of precarity (Campisi \& Vander Kloet, 2019, June), before landing in their current position. Others had performed a related role in another field, such as a business, and a fortuitous event or a job advertisement (often on a website) had resulted in a move into a university position. Rarely had they intended to become research administrators. What seems shared in most descriptions is the element of serendipity.

Although we did not ask directly about gender influences on career patterns or decisions, some of the women spontaneously mentioned issues related to work and family in the context of deciding to go into administration as opposed to academe. For example, Amanda Gilbert had to make some difficult decisions during her postdoc: 'Did I want to start a family? Did I want to start being able to plan for our future? Or did I want to accept another five years or ten years, for instance, of that kind of precarious living?' Stephanie Grant had a similar story:

So when I was in [place], I realized that I didn't see myself working from postdoc to postdoc. I needed something that was more secure [so] that I could go home at the end of the day and tend to my family, and so that's why I decided not to continue on with research. 
Rebecca Smith said that she had applied a few times for academic jobs but 'I don't know, something hit me at one point and I just didn't really want to do it anymore'. She added, 'I kind of like having an end to my day. There are demands of academic lifestyle that aren't for me'.

We asked participants about their future career plans. Two were nearing retirement. Responses of the others suggested that it was hard to plan within this occupational role. Those who were already senior (managers or directors) found it difficult to see where they could go next. Several had directed their excess energy ('brain power that was going to waste', as Eric Lowe put it) into involvement in mentoring, university governance, or association activities in their field. Even at the more junior levels, participants were uncertain about next steps: 'I don't know what the future holds and I'm trying not to think that far ahead' (Andrea Young); 'To be honest I feel a little bit like there is nowhere to go here... I don't know if this is a generational thing or what, but I do feel a bit like, oh what's next' (Candace Vernon). These comments draw attention not only to career patterns but to career prospects in research administration. Those who advocate that the field be regarded as a profession need to take account of the potentially contradictory conclusion that 'there is nowhere to go'.

\section{Discussion}

This article spotlights a group of key players in the university who have received little attention from higher education scholars. Our overall research question was 'How do research administrators in Canadian universities understand their work?' In general terms, we conclude that the RAs in the study understood their work as supporting the research functions of the university and the academics within it. The sub-questions allow more nuanced responses. Our first sub-question asked, 'Do research administrators see their field as a profession and if so, are there elements of praxis involved?' As shown, most of the participants described their field as a profession or an emerging profession. In a few cases, answers pertained to a sub-field such as research ethics administration, knowledge mobilization, or institutional research. For two participants, the professional designation seemed misplaced.

In speaking about research administration as a profession and practice, our participants revealed much about their 'praxis'. Praxis was rarely named as such. However, we considered as praxis reported acts and intentions such as helping academics to flourish (a main preoccupation), improving the quality of research work done in the university, contributing to broader societal improvements through supporting innovation and knowledge mobilization, and creating support 
mechanisms for other research administrators to substitute for the absence of professional development within their institutions ('communities of praxis').

Their intent is not simply to carry out instructions or provide information, it is to make a positive difference. Notably, a prominent element in the RAs' descriptions of work with faculty was helping or caring, perhaps to be expected in a largely female profession, although not confined to our women participants. Men in feminized professions may have a career advantage, but there is also evidence that they can reflect the more generalized values of the field rather than undiluted masculinity (Acker, 1999). The emphasis was most apparent in interviews with RAs who worked in the pre-award sector or whose duties included pre-award work, which often involved talking faculty through emotional responses to rejected proposals or helping junior faculty manage anxieties about establishing a research career. Managers and directors without such direct responsibilities also spoke about caring for their staff, and even a post-award administrator like Stephen Osborne emphasized helping. In describing her data collection and analysis responsibilities, Kathryn Richards used the words help or helping six times. Although mentioned occasionally, little emphasis was placed on managerial values such as efficiency and compliance that have come to be associated with the contemporary university. RAs saw themselves as allies of the faculty rather than bureaucrats or rule-enforcers (Campisi \& Vander Kloet, 2019, June).

Our second sub-question interrogated further the notion that RA work is a profession by comparing statements made by participants to four areas that are frequently understood as elements of professions, namely that there are associations that control entry, that a specific body of knowledge is there to be deployed, that qualifications would be consistent and understood, and that pathways into the occupation would be predictable and standardized. In practice, there was some departure in each of these elements from what might be expected in a prototypical profession. Associations are expanding their remits but do not exert control over entry; there is no consensus on a body of knowledge (which in any case was changing rapidly); expected qualifications are rising but are not specific; and pathways into the occupation are idiosyncratic.

So here we have an interesting contradiction between practitioner sensemaking, which generally supports the existence of a profession, and the many exceptions to the usual rules. We may not be able to resolve this particular contradiction, given that both the definition of 'profession' and the characteristics of research administration are in flux. What qualifies as a profession has clearly been modified from the early trait-theory days (Martimianakis et al., 2009) and, as stated earlier, many varied occupations are seeking such recognition. 
Scholars are working to reframe the historical understanding of university administration as a kind of caste subordinate to the higher-status academic one (Krug, 2015), introducing concepts such as third-space professionals (Whitchurch, 2008), para-academics (Macfarlane, 2011), or hybrid professional managers (Shelley, 2010, p. 49) in order to convey a sense of blurred boundaries between academics and administrators. Although it was clear that RAs held a range of responsibilities that were relatively new and had been upskilled compared with the past, for the most part it was difficult to see them as operating in a new space or taking on formerly academic roles. Our findings are more like those of Gornitzka and Larsen (2004) in Norway and Karlsson and Ryttberg (2016) in Sweden. Gornitzka and Larsen note that most of their administrative staff participants "portray their role as "low key" in the interface with academics and especially in relation to elected academic leaders' (p. 464). They see their role as serving, similar to our emphasis on helping. Karlsson and Ryttberg note that some administrators worked very closely with a particular member of management (also true in our case) and joint strategies might emerge from those partnerships, but on the whole, interviewees were 'clear in not wanting to exercise undue influence' (p. 6). There are parallels with our study, such as Karen Douglas's assertion that she would never want to direct researchers as to where they should put their efforts. It has been suggested that research administration may be a special case where relationships with academics are more harmonious than in other pairings (Allen-Collinson, 2009; Szekeres, 2011). These various findings suggest that more work is needed to compare different administrative specialties as well as different countries.

Those points lead us to examine another apparent contradiction and to ask: 'What tensions are there between the sensemaking of these research administrators about their work and the prevailing critiques of universities as increasingly corporatized, managerial, and audit-based?' There is now an extensive body of literature on neoliberal trends in academe, among them changes in granting structures (Polster, 2007), the spread of new managerialism (Enders et al., 2009), and intensified accountability regimes (Lucas, 2006). These policies are frequently said to have deleterious consequences, including narrowing the nature of research produced (Olssen, 2016) and putting undue pressures on academics to bring money into the university (Petersen, 2016). Contemporary university practices may both enable and constrain efforts at praxis (Mahon et al., 2019).

Given this context, some readers may be inclined to conclude that research administrators are necessarily complicit in furthering a dysfunctional system. Yet it is evident from our interviews that by and large, research administrators see themselves as offering an important and valuable service. There were a few, but 
not many, references to the neoliberal turn within universities, such as comments about the pressure academics are under to secure grants and publish prolifically. It is not that the RAs are uncritical: there are many critical remarks in the interviews about the research councils, university hierarchies and procedures, and other aspects of their work surroundings. But it is illogical to expect critiques that undermine their own contributions.

This point leads to another question about the net impact of these changes over time on research administrators. We could see them as having been re-skilled and their positions upgraded and improved. That interpretation leads us to consider the neoliberalization of the university in a more positive way than is usually understood: for some, it provides opportunities. Although academics are frequently understood as 'playing the game' in order to succeed in the research world (Leathwood \& Read, 2013; Lucas, 2006), that does not mean that administrators should also be characterized similarly. Rather than imposing potential interpretations about the complicity of RAs in furthering a system harmful to academics, we believe that RAs' sensemaking around professionalization and praxis and their self-images as contributors to faculty well-being through helping and caring should not be brushed aside by critical scholars.

From the perspectives of our participants, research administrators engage in praxis and are a helping profession in several senses. They help each other to learn 'on the job'. They help to enhance the greater good of the university and the quality of the research enterprise. In that process, they help academics to conform to expectations, including those that may be unjust and stressful. Yet (ironically?) through their praxis, they also make working life more bearable and rewarding both for themselves and their academic colleagues.

\section{Conclusion}

A number of limitations and potential extensions of our work can be outlined. Interview-based data like ours always produce a snapshot of what people choose to tell at a particular moment in time. And as a small, qualitative study in one province in Canada, generalizations are necessarily limited. Nevertheless, given the neglect by scholars of the various staff other than academics who make up a large proportion of universities, and the near-absence of Canadian research on research administrators, a small study is heuristic and worthwhile. We have not had space to comment on institutional variations, although some do appear. The range of roles and responsibilities within the RA group has also added both to the strength of the study and the weakness, as a generalization applicable to a pre- 
award RA in a faculty of social sciences might not apply to an RA in a central unit specializing in research data management or knowledge mobilization.

Differences among administrative subgroups including and going beyond research administration need further investigation. Many published studies combine rather disparate specialties. We also suggest that more work be done to illuminate differences among countries. To what extent, for example, does the UK's Research Excellence Framework shape prevailing scholarship, often from the UK, about new divisions of university labour? How might such divisions differ in cases where the audit culture is less prominent or varies in other ways? Research in Canada can be an important corrective or an extension of ideas around how to understand changing academic (and by extension, administrative) work (Acker \& Webber, 2016). Canada is unusual in not having a federal department of education (Shanahan \& Jones, 2007), instead delegating educational responsibility to provinces, as well as retaining strong academic tenure systems and functioning unions for many university workers (Jones, 2013). Thus, Canada has no centrally directed research assessment exercises, although some provinces are beginning to impose versions of performance funding. Nonetheless, expectations for publishing and securing grants have increased and even spread to institutions without strong research profiles. Elsewhere we have described Canadian academics as uneasy rather than in despair (Acker \& Webber, 2016).

The example of the RAs also suggests that analysis of the gendered academy needs to go beyond academics alone. Administrators in universities perform many tasks that appear to parallel those in occupations that Bourdieu (1992) called the 'left hand of the State' or 'social work' (see also Acker \& Dillabough, 2007) and that we have characterized here as 'helping'. Gender scholarship needs to expand to consider the full gendered and raced profile of the university and what mechanisms sustain or challenge the divisions of labour, opportunity, and reward among administrative and other staff groups as well as academics.

Finally, the age-old debate about structure versus agency has arisen in our analysis, if not by name. Although there are many points at which structure limits what people can do, as evident in the description of aspects of what might, or might not, be a profession, we have made efforts to take agency seriously and not to undermine the sensemaking of the research administrators or their efforts at praxis by superimposing an interpretation upon their work lives that is at odds with their own. 


\section{Author biographies}

Sandra Acker has held academic positions in the United States, the United Kingdom, and Canada. She is a sociologist of education whose research has highlighted gender and other equity issues in the careers and workplace cultures of teachers, doctoral students, academics, and academic administrators. She is the principal investigator for the Academic Researchers in Challenging Times project from which this article is drawn.

Michelle K. McGinn is Interim Associate Vice-President Research and Professor of Education at Brock University in St. Catharines, Ontario, Canada. Her primary interests relate to research collaboration, researcher development, scholarly writing, and ethics in academic practice. She is a co-investigator on the Academic Researchers in Challenging Times project.

Caitlin Campisi is a doctoral candidate in the Department of Social Justice Education, University of Toronto, Ontario, Canada, studying doctoral student retention in the Canadian academy. She also serves as the Executive Director of the Association of Part-Time Undergraduate Students at the University of Toronto. She is the Research Coordinator for the Academic Researchers in Challenging Times project. 


\section{References}

Acker, S. (1999). The realities of teachers' work: Never a dull moment. London and New York: Cassell/Continuum.

Acker, S., \& Dillabough, J.-A. (2007). Women 'learning to labour' in the 'male emporium': Exploring gendered work in teacher education. Gender and Education, 19(3), 297-316.

Acker, S., \& Haque, E. (2017). Left out in the academic field: Doctoral graduates deal with a decade of disappearing jobs. Canadian Journal of Higher Education, 47(3), 101-119.

Acker, S., \& Webber, M. (2016). Uneasy academic subjectivities in the contemporary Ontario university. In J. Smith, J. Rattray, T. Peseta, \& D. Loads (Eds.), Identity work in the contemporary university (pp. 61-75). Rotterdam, Netherlands: Sense.

Acker, S., \& Ylijoki, O.-H. (2018, July). Grant hunting in corporatized universities: Experiences from Canada and Finland. Paper presented at the International Sociological Association Conference, Toronto, Canada.

Adams, T. L. (2015). Sociology of professions: International divergences and research directions. Work, Employment and Society, 29(1), 154-165.

Allen-Collinson, J. (2006). Just 'non-academics'? Research administrators and contested occupational identity. Work, Employment and Society, 20(2), 267288.

Allen-Collinson, J. (2007). 'Get yourself some nice, neat, matching box files!' Research administrators and occupational identity work. Studies in Higher Education, 32(3), 295-309.

Allen-Collinson, J. (2009). Negative 'marking'? University research administrators and the contestation of moral exclusion. Studies in Higher Education, 34(8), 941-954.

Anderson, M. J., \& Freebody, K. (2012). Developing communities of praxis: Bridging the theory practice divide in teacher education. McGill Journal of Education 47(3), 359-378.

Angervall, P., \& Beach, D. (2017). Dividing academic work: Gender and academic career at Swedish universities. Gender and Education. Advance online publication. doi:10.1080/09540253.2017.1401047

Angervall, P., Beach, D., \& Gustafsson, J. (2015). The unacknowledged value of female academic labour power for male research careers. Higher Education Research \& Development, 34(5), 815-827.

Berman, J. E., \& Pitman, T. (2010). Occupying a 'third space': Research trained professional staff in Australian universities. Higher Education, 60(2), 157169. 
Bourdieu, P. (1992, January 14). The left hand and the right hand of the state. Interview by R. P. Droit and T. Ferenczi, Le Monde. Retrieved 2019-10-21 from http://www.variant.org.uk/32texts/bourdieu32.html

Campisi, C., \& Vander Kloet, M. (2019, June). Meaningful work? Alt-ac careers in research administration and faculty-staff relations. Paper presented at the Canadian Society for the Study of Higher Education annual conference, Vancouver, BC, Canada.

Cascio, M. A., Lee, E., Vaudrin, N., \& Freedman, D. A. (2019). A team-based approach to open coding: Considerations for creating intercoder consensus. Field Methods, 31(2), 116-130.

Charmaz, K. (2010). Grounded theory: Objectivist and constructivist methods. In W. Luttrell (Ed.), Qualitative educational research: Readings in reflexive methodology and transformative practice (pp. 183-207). New York: Routledge.

Cox, A. M., \& Verbaan, E. (2016). How academic librarians, IT staff, and research administrators perceive and relate to research. Library \& Information Science Research, 38(4), 319-326.

Degn, L. (2018). Academic sensemaking and behavioural responses_Exploring how academics perceive and respond to identity threats in times of turmoil. Studies in Higher Education, 43(2), 305-321.

Enders, J., de Boer, H., \& Leišytè, L. (2009). New public management and the academic profession: The rationalisation of academic work revisited. In J. Enders \& E. de Weert (Eds.), The changing face of academic life (pp. 3657). London, UK: Palgrave Macmillan.

Eveline, J. (2004). Ivory basement leadership: Power and invisibility in the changing university. Crawley: University of Western Australia Press.

Evetts, J. (2011). Sociological analysis of professionalism: Past, present and future. Comparative Sociology, 10(1), 1-37.

Ginsberg, B. (2011). The fall of the faculty: The rise of the all-administrative university and why it matters. New York, NY: Oxford University Press.

Gornitzka, Å., \& Larsen, I. M. (2004). Towards professionalisation? Restructuring of administrative work force in universities. Higher Education, 47(4), 455-471.

Jones, G. A. (2013). The horizontal and vertical fragmentation of academic work and the challenge for academic governance and leadership. Asia Pacific Education Review, 14(1), 75-83.

Karlsson, S., \& Ryttberg, M. (2016). Those who walk the talk: The role of administrative professionals in transforming universities into strategic actors. Nordic Journal of Studies in Educational Policy, 2016(2-3), Art 31537. 
Kemmis, S. (2012). Researching educational praxis: Spectator and participant perspectives. British Educational Research Journal, 38(6), 885-905.

Kerridge, S., \& Scott, S. F. (2018). Research administration around the world. Research Management Review, 23(1), 1-34.

Kozaitis, K. (2013). Anthropological praxis in higher education. Annals of Anthropological Practice, 37(1), 133-155.

Krug, K. (2015). It's not just the glass ceiling, it's the caste ceiling. In E. Whittaker (Ed.), Solitudes of the workplace: Women in universities (pp. 172-190). Montreal \& Kingston: McGill-Queen's University Press.

Larson, M. S. (2018). Professions today: Self-criticism and reflections for the future. Sociologia, Problemas E Práticas, (88), 27-42.

Leathwood, C., \& Read, B. (2013). Research policy and academic performativity: Compliance, contestation and complicity. Studies in Higher Education, $38(8), 1162-1174$.

Losinger, I. (2015). The non-nons: Secretarial and clerical staff. In E. Whittaker (Ed.), Solitudes of the workplace: Women in universities (pp. 156-171). Montreal \& Kingston: McGill-Queen's University Press.

Lucas, L. (2006). The research game in academic life. Maidenhead, UK: Open University Press.

Luukkonen, T., \& Thomas, D. (2016). The 'negotiated space' of university researchers' pursuit of a research agenda. Minerva, 54(1), 99-127.

Macfarlane, B. (2011). The morphing of academic practice: Unbundling and the rise of the para-academic. Higher Education Quarterly, 65(1), 59-73.

Mahon, K., Heikkinen, H. L. T., \& Huttunen, R. (2019). Critical educational praxis in university ecosystems: Enablers and constraints. Pedagogy, Culture and Society, 27(3), 463-480.

Maitlis, S., \& Sonenshein, S. (2010). Sensemaking in crisis and change: Inspiration and insights from Weick (1988). Journal of Management Studies, 47(3), 551-580.

Martimianakis, M. A., Maniate, J. M., \& Hodges, B. D. (2009). Sociological interpretations of professionalism. Medical Education, 43(9), 829-837.

McGinn, M. K. (2012). Being academic researchers: Navigating pleasures and pains in the current Canadian context. Workplace, (21), 14-24.

McGinn, M. K., Acker, S., Vander Kloet, M., \& Wagner, A. (2019). Dear SSHRC, what do you want? An epistolary narrative of expertise, identity, and time in grant writing. Forum: Qualitative Social Research, 20(1), Art 8.

Noordegraaf, M. (2007). From 'pure' to 'hybrid' professionalism: Present-day professionalism in ambiguous public domains. Administration \& Society, 39(6), 761-785. 
Olssen, M. (2016). Neoliberal competition in higher education today: Research, accountability and impact. British Journal of Sociology of Education, 37(1), 129-148.

Paton, S., Hodgson, D., \& Muzio, D. (2013). The price of corporate professionalisation: Analysing the corporate capture of professions in the UK. New Technology, Work and Employment, 28(3), 227-240.

Pearson, A. K. (2008). Disrespectin' administrative staff work: Can we talk? In A. Wagner, S. Acker, \& K. Mayuzumi (Eds.), Whose university is it, anyway? Power and privilege on gendered terrain (pp. 127-139). Toronto: Sumach.

Petersen, E. B. (2016). The grant game as training ground for tractability? An Australian early career researcher's story. Research in Education, 96(1), $46-51$.

Polster, C. (2007). The nature and implications of the growing importance of research grants to Canadian universities and academics. Higher Education, 53(5), 599-622.

Reed, C. (2018). Professionalizing corporate professions: Professionalization as identity project. Management Learning, 49(2), 222-238.

Ricketts, K., \& Pringle, J. K. (2014). Going up? Perceived career progress of female general staff across New Zealand universities. Journal of Higher Education Policy and Management, 36(5), 496-508.

Ryttberg, M., \& Geschwind, L. (2017). Professional support staff at higher education institutions in Sweden: Roles and success factors for the job. Tertiary Education and Management, 23(4), 334-346.

Sebalj, D., Holbrook, A., \& Bourke, S. (2012). The rise of 'professional staff' and demise of the 'non-academic': A study of university staffing nomenclature preferences. Journal of Higher Education Policy and Management, 34(5), 463-472.

Shambrook, J., Lasrado, V., Roberts, T. J., \& O’Neal, T. (2015, October). 2015 profile of a research administrator. Poster presented at the Society for Research Administrators International symposium, Las Vegas, NV. Retrieved 2019-10-21 from https://www.semanticscholar.org/paper/2015Profile-of-a-Research-Administrator-ShambrookLasrado/b7ab3c86e48a6f2dbcf0a7584e2c8488178c52a5

Shanahan, T., \& Jones, G.A. (2007). Shifting roles and approaches: Government coordination of post-secondary education in Canada, 1995-2006. Higher Education Research \& Development, 26(1), 31-43.

Shelley, L. (2010). Research managers uncovered: Changing roles and 'shifting arenas' in the academy. Higher Education Quarterly, 64(1), 41-64.

Shore, C., \& Wright, S. (2015). Audit culture revisited: Rankings, ratings, and the reassembling of society. Current Anthropology, 56(3), 421-444. 
Simpson, A., \& Fitzgerald, T. (2014). Organisational and occupational boundaries in Australian universities: The hierarchical positioning of female professional staff. Studies in Higher Education, 39(10), 1929-1941.

Szekeres, J. (2004). The invisible workers. Journal of Higher Education Policy and Management, 26(1), 7-22.

Szekeres, J. (2011). Professional staff carve out a new space. Journal of Higher Education Policy and Management, 33(6), 679-691.

Weick, K. E. (1988). Enacted sensemaking in crisis situations. Journal of Management Studies, 25(4), 305-317.

Whitchurch, C. (2008). Shifting identities and blurring boundaries: The emergence of third space professionals in UK higher education. Higher Education Quarterly, 62(4), 377-396.

Zornes, D. (2019, February). Research administration as a profession: RAAAP project. Canadian Association of Research Administrators webinar presentation. 